\title{
Corporate Strategy, Governance Structure and Organization Performance: A Research Agenda
}

\author{
Fatuma B. Omar ${ }^{1} \&$ James M. Kilika ${ }^{2}$ \\ ${ }^{1}$ Doctoral Student, Department of Business Administration, School of Business, Kenyatta University, Kenya \\ ${ }^{2}$ Lecturer, Department of Business Administration, Kenyatta University, Kenya \\ Correspondence: James M. Kilika, Department of Business Administration, School of Business, Kenyatta University, \\ Kenya.
}

Received: May 2, 2018

Accepted: May 28, 2018

Online Published: May 29, 2018

doi:10.5430/bmr.v7n2p49

URL: https://doi.org/10.5430/bmr.v7n2p49

\begin{abstract}
Corporate strategy plays a critical role in the proper functioning of an organization as it provides the blueprint that guides the corporate direction of an organization while governance structure presents an organization with a framework for the distribution of responsibilities and resources to achieve organization performance. While the constructs have been sufficiently studied and documented in various studies separately in relation to organization performance, few studies have been undertaken to study the two constructs together to understand how they jointly explain organization performance. This paper presents a review of the extant theoretical and empirical literature on the two constructs in relation to organization performance. Relevant underpinning theories are reviewed, constructs described and their operational indicators identified and compared with empirical work and emergent knowledge gaps identified. The paper finally proposes a multidisciplinary based theoretical model suitable to address the gaps identified to advance knowledge in the area and calls upon future research to empirically test the propositions of the study.
\end{abstract}

Keywords: corporate strategy, governance structure, organization performance, industry life-cycle, firm competitive position

\section{Introduction}

There has been a great deal of both public and private commercial entities failing as a result of reasons connected with corporate strategy and governance structure. These two factors determine the direction a corporate entity is to head. Globalization and other environmental factors are likely to affect organizations adversely if an organization has not properly defined its corporate strategy or governance structure. Christensen (2006) and Child (1972) argued that corporate strategies provide an organizational roadmap while governance structure directs and controls organization's activities to achieve desired performance. Each organization needs to demonstrate a sense of ownership of the strategies adopted as well as the systems for implementation. For organizations to perform effectively, they must first understand their environment, formulate their own strategies and create structures that can implement the formulated strategies without difficulties (Mintzberg, 1987).

Strategy exists in three levels in an organization; corporate, business and operational levels. Corporate Strategy provides the direction over a period of time in a changing environment by indicating how an organization's resources and competences will be configured to achieve stakeholder expectations (Johnson, Scholes, \& Whittington, 2010). It constitutes the moves and approaches adopted by managers to grow the business and achieve targeted levels of organizational performance (Thompson Jr, Strickland III, \& Gamble, 2008). The Corporate level of strategy directs the overall purpose of an entity and outlines how value is to be added to the company. Business level strategies are concerned with business competitiveness while operational strategies deal with the way the organization delivers business and corporate strategies in regard to its resources. Corporate strategy represents the managerial game plan for an organization to achieve its objectives and stakeholders expectations (Thompson, \& Strickland, 1996). It involves the moves employed to establish a competitive position in different industries and the program used to manage the company's group of businesses. It is made at the top level of management of an organization and applies to the entire organization. They are made by the management team and are reviewed and approved by the board (Thompson, \& Strickland, 1996). The decisions leading to a corporate strategy have been described to have an impact on the 
organization as they focus on the long term and are characterised by heavy financial commitment (Pearce \& Robinson, 2011; Hofer \& Schendel, 1979).

Governance structures are systems, rules, norms, practices and processes which are used to direct and control a company (Malmi, \& Brown, 2008). Governance structure entails the process of balancing the interests of stakeholders of a company such as shareholders, management team, suppliers, financiers, clients, the community and government (Freeman, 2010). It provides the framework for achieving the objectives of an organization and it involves every aspect of management from plans, programs and internal controls to measurement of performance and disclosure. Scott and Davis (2015) argued that governance chain entails the roles and relationships of different groups involved in the operation of a company and determined by the ownership structure of an organization where it is simple in family owned entities and complex in large private and public owned companies. The types of governance structure that an organization may adopt are guided by the shareholder model and stakeholder model (block holder systems of governance). Governance structure determines the success or failure of an organization because it guides on how an organization delegates or engages with the management of an organization. Governance structure is mostly determined by ownership structure of an organization (Johnson, Scholes \& Whittington, 2008).

\subsection{Statement of the Problem}

There have been discussions on whether it is corporate strategy or governance structure that influences the performance of organizations (Govindarajan \& Fisher, 1990) and how the two relate in terms of program implementation and organization performance management. The conflicting results from earlier studies have prompted debate on whether corporate strategy, governance structure and organization performance are elements that need to be looked at and studied together to identify gaps in performance of an organization (Kaplan \& Norton, 2001). The three constructs are critical in the survival of any organization and therefore important for academic inquiry. In order to advance scholarship in this area, there is need to consolidate the understanding of the constructs and their operational indicators. Secondly, the linking of the constructs of governance structure with the right indicators of performance based on the broader perspective or view of performance has been lacking in most studies reviewed (Marashdeh, 2014; Vo \& Phan, 2013; Heenetigala, 2011). Thirdly, the scope of the current understanding of the construct of performance is limiting; whereas the current understanding takes a narrow aspect of the construct, the stakeholder based perspective raises the need for a broader view of the construct of performance which also implies that a relevant set of theoretical underpinnings are required.

There has also been a limited set of theoretical models to comprehensively address outcomes of the phenomena stretching from those that address phases of organizational strategy to those addressing performance and a general lack of overriding theory that links all the constructs of corporate strategy, governance structure and performance. Additionally from the literature reviewed, it was discovered that the strategic management phenomenon involving the three constructs invites a wider range of constructs and theoretical underpinnings than those identified by approaches that have relied on the narrow approach (Okiro, Aduda, \& Omoro, 2015; Aftab, Ehsan, Naseer, \& Awan, 2012; Santos \& Brito, 2001; Anwar, Shah \& Hasnu, 2016; Oyedijo \& Akewusola, 2012; Kalkana, Erdilb \& Çetinkayac, 2011; \& Sougata Ray, 2004).

In light of the above, the study addressed the gaps highlighted as well as attempting to respond to the call for further research as proposed by studies done by various researchers in the past assessing the relationship that exists between corporate strategy, governance structure and organizational performance in order to make recommendations on how they can be applied to enhance the body of knowledge in strategic management (Oyedijo \& Akewusola, 2012; Awaluddin, 2014; Marashdeh, 2014; Munyoki (2015). The following objectives guided the study; first, the study reviewed the extant theoretical and empirical literatures to identify the current understanding of the constructs. Secondly, the study identified the emerging issues pointing to conceptual, theoretical and empirical gaps that form the basis for future research on corporate strategy, governance structure and organization performance. Finally the study proposed a theoretical framework to address the conceptual, theoretical and empirical gaps identified.

In undertaking the current study, the authors acknowledge the need to generate a comprehensive multidisciplinary based model in strategic management for informing the direction for future research. Given the current developments in the social and economic environments for business, there are emerging calls for the discipline to expand its view so as to integrate perspectives that offer capability to measure and empirically report on such attributes as sustainability and stakeholder dimensions. The current paper draws from a rich multidisciplinary background which the authors hope will further enhance the rich repository of knowledge in strategic management. The proposed framework and set of propositions will offer a useful direction along which scholarship will identify relevant lines of investigation. 


\section{Conceptual Review of the Literature}

To address the study objectives, the paper presents various conceptual perspectives so as to provide an understanding of the nature of the constructs and the phenomenon they bring about in strategic management. The emerging issues arising from the literature are identified and discussed with a view to pointing at the direction for further conceptualization and theorizing in strategic management.

\subsection{Corporate Strategy}

The concept of corporate strategy as a point of interest in strategic management has its roots in the concept of levels of strategic management. Traced from this background, this section discusses the roots of corporate strategy, the nature of corporate strategy as well as the various types of corporate strategies applied in organizations. The roots towards understanding of corporate strategy lie in the nature of management strategy as understood in strategic management. To understand corporate strategy it is important to understand what management strategy is all about. Many researchers and scholars have undertaken to define the concept with no conventional definition being agreed upon. However they all agree that strategy is the road map to direct an organization to achieve intended objectives. Johnson, Scholes and Whittington (2010) define strategy as the direction over a period of time in a changing environment by its resources and competences configuration to achieve stakeholder expectations. It constitutes the moves and approaches that managers adopt to grow the business and achieve targeted organizational performance (Thompson Jr, Strickland III \& Gamble, 2008). Johnson et al., (2010) explain that strategy exists in a number of levels in an organization which are corporate, business and operational.

Corporate level strategy directs the overall purpose of an entity and outlines how value is added to the company. Business level strategy is concerned with business competitiveness while operational strategy deals with the way the organization delivers business and corporate strategies in regards to its resources and people. Thompson Jr, et al., (2008) define corporate strategy as programmes the company employs to establish a corporate position in an industry, the moves corporate executives follow to increase the performance of the portfolios a company has diversified into and the process of achieving business synergies and converting them into competitive advantages. On the other hand Thompson, and Strickland, (1996) defined corporate strategy as the managerial game plan to achieve organizational goals and objectives. Corporate strategies are the decisions in an organization that determine its goals and provide the policies, plans and programs to achieve them and define the portfolios of business opportunities the company can undertake. Corporate strategies apply to the entire enterprise and are crafted at the top level of the governance structure. To achieve long-term corporate success, corporate managers need to establish long-term objectives to form the basis of directing the firm's performance. Designing and implementing the appropriate corporate strategies enables an organization to achieve productivity, profitability, competitive position, technological leadership, employee relations, employee development and social responsibility throughout its operation. Corporate strategies that an organization develops must be flexible, motivating, suitable, measurable and understandable (Pearce \& Robinson, 2011).

The focus of the corporate strategies is aimed at confronting the phase in which the organization finds itself in and survive towards its future. There are three phases that the literature points to as characterising the context of most of the organizations; growth, maturity and decline. Corporate strategies developed by top managers and corporate strategists are aimed to address the three phases organizations encounter during their operations and this helps them to achieve planned organization performance. Freeman (2010) argued that corporate managers have to undertake critical strategic thinking sessions to address the challenges arising from the three phases to enable the organization to compete effectively and meet its stakeholders' expectations. Greiner (1972) argued that managerial problems are rooted in time and do not last right through the life of an organization and thus companies undergo growth phase due to changing times.

The types of corporate strategies that a company may adopt in its operation to remain relevant and address organization life cycle challenges as mentioned above are growth, stability and concentration strategies (Sekhar, 2009). Greiner (1972) cited that, during the growth phase, organizations employ creativity, directional delegation, coordination and collaboration processes and adopt functional structure based on; accounting systems, incentives, budgets, standards of work and communication becomes formal and impersonal. He identified key organizational dimensions that affect organization's growth; age and size of an organization, organization stage of evolution and revolution and its industry growth rate. The characteristics of growth phase are the ability to establish strong brands through promotions, the ability to meet demands by customers, strong production skills, ability to differentiate, research and development ability, client retention ability and strong capability to sale and market its products (Pearce \& Robinson, 2011). 
An organization at growth phase will endeavour to gain product and market expansion grid through market penetration where it strives to obtain more market share with its current products in their current markets, market development by developing new market for its current products, product development where it develops new products for potential interest for its existing market and finally diversify through reviewing opportunities to develop new products for new markets. To achieve growth through market penetration, market development, product development and diversification, corporate managers design and implement corporate strategies such as, Intensive growth strategies (market development and penetration strategy and product development strategy); Integrative growth Strategies (horizontal and vertical integration strategy) and Diversification Strategies (concentric diversification and conglomerate diversification strategies), (Pearce \& Robinson, 2011). At growth phase, organizations can also use the BCG model to develop corporate strategies by adopting the stars and cash cow quadrants.

At the maturity phase, the growth rate declines due to changes in the operating environment and intensified competition for market share (Pearce \& Robinson , 2011). At maturity phase organizations experience a slowdown in sales growth because the products have achieved acceptance by most potential buyers. Profits either stabilize or decline because of increased competition. Kotler and Keller (2013) observe that in the maturity stage organizations distinguish themselves into three types, namely: quality leaders, service leaders and cost leaders. Surrounding them are market nichers (market specialists, product specialist and customizers). The questions to corporate strategists are whether to struggle and become one of the big three and achieve profits through high volumes and low cost or pursue a niching strategy and profit by low volumes and high margins. Reeves and Tillmanns (2012) argued that at maturity phase corporate strategists adopt stability strategies (Holding, Harvesting and Profit/Endgame Strategies) to overcome the challenges of organization maturity phase. They may also adopt research and development actions to maintain their strengths and build on weakness.

If strategists fail to act to avert maturity challenges, the organization will inevitably slip into decline phase. Decline phase is characterized by drop in company sales resulting from technological advancement, shifts in customers' tastes and increased competition and to survive they can employ divesting strategies (Kotler \& Keller, 2013). This will help to reduce on loss making ventures so as to create strategic options in areas it can invest in to grow and achieve its strategic objective. Corporate strategies that can be applied during this phase are Retrenchment Strategies; (turnaround, divestiture, liquidation and bankruptcy strategies) (Pearce \& Robinson, 2011).

\subsection{Governance Structure}

To enable an organization achieve its corporate strategy, it has to design and develop implementation and control systems that ensure achievement of the desired results. These systems are called governance structure and they can determine the success or failure of an adopted corporate strategy. Governance structure stems from the concept of governance which has its roots in the control function of management. Management controls are defined as a systematic attempt to compare performance to pre-determined standards and address performance deficiencies. Wildavsky (1973) cited the role of control as being that of validating whether everything happens in compliance with the adopted plans, issued instructions and established principles. Governance is defined as the enactment of policies and continuous evaluation of their proper implementation by the governing body of an organization (Rezaee, 2009). It involves the systems required to balance the powers, corresponding accountability and duty of the governing body to enhance the prosperity and viability of the organization. Further, it has also been defined as how norms, rules and actions are designed, regulated, sustained and held accountable (Risse, 2004). Greiner (1972) in his work on evolution and revolution as organizations grow, captions that management practices that work well in one phase may bring a crisis in another and highlights five phases of company growth and links them to governance structure dimensions such as organization structure, top management style and control systems as the determining factors for success or failure of a given phase.

The Board of Directors represents the top management of the organization (Pfeffer, 1973) that sets policies, procedures and long-term plans to meet organizational objectives. The board does this through a governance structure. Governance Structure is the system of rules, processes and programs by which an organization is directed and controlled. It entails balancing the interests of an organization's stakeholders like shareholders, management, customers, suppliers, financiers, government and the community. Governance structure describes the purposes and priorities of the organization. This concerns the way an organization functions and how distribution of power among different stakeholders is ensured (Arthur, Thompson Jr, Strickland III \& Gamble, 2008).

Generally the concept of governance tasks directors and the managers to be knowledgeable on the expectations of a company's stakeholders; actively work on their behalf and keep them informed. However the principal-agent model is 
a reminder that agents may work in their own self-interest and need encouragement to work in the interest of the principal. This can be accomplished by either adopting a particular outcome such as financial performance or use of performance-related incentive. Equally, corporate governance systems can be extended to monitor the agent's behaviour (Johnson et al., 2008). Senior managers have responsibility for designing and implementing a company's strategy and the board of directors' duty is to apply strong oversight and see that the tasks of strategic management are undertaken in a manner that benefits organization's stakeholders (Thompson Jr, et al., 2008).

Governance structure enhances the sustainable development of stakeholder interests, effective management, and discharge of social responsibility and application of best management practice to ensure excellent organizational performance. It enhances legal, regulatory and ethical compliance of an entity. Governance structure is highly essential because it advances sustainable growth and performance of the organization by regulating and controlling the possible and likely misleading, immoral and unethical acts of Chief Executive Officers (Rezaee, 2009).

\subsection{Organization Performance}

Organizational performance is the actual output and results of an organization as measured against its predetermined objectives. Richard, Devinney, Yip and Johnson (2009) argued that organizational performance entails three areas of performance outcomes which are financial performance outcomes such as profits, return on assets, return on investment; product-market performance such as sales, market share; and shareholder return in total shareholder return and economic value additions. The objective of any organization is to achieve high performance rank in comparison to its competitors in the industry and it is an indicator of the commercial health of any given organization which will impact on its stakeholder return value as well as its stand in the industry. Organization's performance is widely used as a dependent variable in management studies even though it has attracted criticism based on the loose and vague nature of its definition.

From the literature reviewed, organizational performance has either been operationalized through financial or non-financial indicators and accordingly their source of data were either primary or secondary or both. Organizational performance may be measured either as financial or nonfinancial outcome based on the indictors employed as dictated by the concepts and context of a research. Financial performance aspect of organization performance has been the dominant model in empirical management research (Galbraith, \& Schendel, 1983; Hofer, 1983) and mostly indicated as sales growth, profitability (return on sale, return on investment and return on equity) and share earnings. They reflect the fulfillment of the economic objectives of an organization. Non-financial performance perspective of organization performance measures include indicators such as introduction of new product, product quality, marketing effectiveness, value-additions, market-share and additional measures of technological efficiency within the organization's performance matrix. The adoption of either of the organization performance perspective has generated divergent views and is directed by the organization's objectives as generated by organization's stakeholders.

Organizations in recent years have tried to manage performance through the balanced scorecard approach, where performance is monitored and measured in multiple dimensions; financial performance, customer service, corporate social responsibility, employee relations, performance improvement and organization engineering. Organizational Performance should be regularly assessed to identify if there are gaps and results are deviating from the strategic plan (Ansoff, 1980). These performance gaps determine if corporate strategy and governance structure in place are effective or need to be reviewed. In line with these performance reviews the organization should also undertake to assess if their stakeholders are satisfied with the performance of the organization to earn their approval as a major partner especially the shareholders. Kuratko, Covin, and Garrett, (2009) argued that firms are in various ventures to succeed and therefore performance is a crucial organizational aspect and remains at the heart of strategic management. Muchemi (2014) argued that organizational performance is characterized by efficiency and effectiveness in utilization of resources as well as the accomplishment of its goals. Researchers agree that the kind of performance an organization will deliver will be dependent on the corporate strategy developed and implemented as well as the governance structure in place such that the more superior the corporate strategy of an organization, the more superior the performance of an organization will be.

\subsection{Issues Arising from Conceptual Review}

From the literature reviewed, four issues stand out. First is an understanding of the constructs and the operational indicators of the constructs of corporate strategy, governance structure and organization performance. The reviewed conceptual literature shows evidence of an extensive effort made by management scholars to define corporate strategy, governance structure and organization performance in a way that provides a clear understanding of conceptual and contextual aspects of the constructs and indicated how they can be applied in strategic management. 
The scholars also operationalized the constructs via indicators that can easily provide a path to describing the nature of relationships among the constructs.

Second, is the fact that the depth of the current scope of understanding of the construct of performance is limiting; whereas the current understanding takes a narrow aspect of the construct, the stakeholder based perspective raises the need for a broader view of the construct of performance which also implies that a relevant set of theoretical underpinnings are required. In the same breadth, there is a limited set of theoretical models to comprehensively address outcomes of the phenomena stretching from those that address phases of organizational strategy to those addressing performance and general lack of overriding theory that links all the constructs of the study (Anwar, Shah \& Hasnu, 2016; Oyedijo \& Akewusola 2012; Aftab, Ehsan, Naseer \& Awan, 2012; Kalkana, Erdilb \& Çetinkayac ,2011; Ray 2004).

The extant empirical literature reviewed indicates that previous researchers applied these constructs in empirical work. For example Awaluddin (2014) studied the effect of corporate strategy to company performance, where the researcher operationalized corporate strategy as portfolio strategy, directional strategy and parenting strategy and company performance as company's profitability, sales dimension and market share; Oyendiyo and Akewusola (2012) conducted a study on Organizational strategy and firm performance where organizational strategy was operationalized as analyzer, defender and reactor strategies and firm performance as product and market innovation, risk taking and proactive response and gross revenue. Aftab, Ehsan, Naseer and Awan (2012) undertook a study on the effect of corporate strategy and capital structure on performance as the study operationalized corporate strategy as Strategic adaptation and performance as economic liberation; Kalkana, Erdilb and Çetinkayac (2011) considered the relationships between firm size, prospector strategy, architecture of information technology and linked them to firm performance as the researchers approached prospector strategy as a form of corporate strategy and influenced by technology and linking them to performance; and Ray (2004) researched on Environment-Strategy-Performance Linkages. Corporate strategy was operationalized as strategic adaptation and scale expansion strategy while performance was gauged as profitability and market performance and economic liberalization.

Researchers have also assessed the relationship between governance structure and performance where Okiro, Aduda and Omoro (2015) assessed the effect of corporate governance and capital structure on performance of companies listed at the East African community securities exchange where governance structure was operationalized as board composition, structure, remuneration, shareholding and ownership, transparency, disclosure and auditing, and corporate ethics while performance as; return on investment; Fratini and Tettamanzi, (2015) studied corporate governance and performance and conceptualized governance structure as board structure, ownership, and capitalization; and performance as company performance; Marashdeh, (2014) assessed the effect of corporate governance on firm performance. Governance structure was conceptualized as ownership, board size, CEO duality and duality effect, while performance was operationalized as financial performance; Vo and Phan (2013) assessed the effect of corporate governance on firm performance; governance structure was depicted as board size, board composition, board compensation, board member education and experience and CEO duality and performance indicated as return on asset; Heenetigala (2011) studied corporate governance practices and firm performance of listed companies in Sri Lanka where governance structure was operationalized as board composition and performance as return on equity and assets.

In addition, researchers assessed organization performance in relationship to other parameters outside the study constructs and these studies are; Anwar, Shah and Hasnu (2016) who conducted a study on Business Strategy and Organizational Performance where performance was operationalized as financial performance; Munyoki, (2015) undertook a study on the joint influence of organizational autonomy, positioning and competitive strategies on performance of Kenyan State Corporations where performance was operationalized as financial and non-financial measures and finally Santos and Brito (2012) conducted a study aimed at proposing a subjective measurement model for firm performance in firms where performance was depicted as profitability, growth, customer and employee satisfaction.

In light of the above, a crystal analysis of the researches shows that the researchers applied a wide array of constructs that are beyond those captured in the conceptual literature and go beyond the scope of the mother disciplines (Marshall \& Rossman, 2014). For example, the researchers have introduced the constructs of capital structure (Okiro, Aduda, \& Omoro, 2015; \& Aftab, Ehsan, Naseer, \& Awan, 2012) and subjective measurement model (Santos \& Brito, 2001). In addition, while the conceptual literature is unclear on the indicators of governance structure, the empirical studies have been quite precise on the operational indicators of the construct. Generally, across the researches, the researchers applied comprehensive conceptualization and theory building that cuts across multiple disciplines to 
analyse the relationships among the constructs (Tashakkori, \& Teddlie, 2010). Combining these approaches together with other discoveries that characterize research in strategic management, the authors are of the opinion that the phenomenon involving the constructs of the study will need the input of several theories which are relied upon to construct the theoretical framework.

\subsection{Review of Relevant Theories}

The literature so far reviewed on the constructs understudy indicates that there are theories that have been used to further the knowledge on the constructs. The theoretical underpinnings relating to these concepts and constructs are agency theory, institutional theory, upper echelons theory, life cycle theory, stakeholder theory and balance scorecard approach.

\subsubsection{Agency Theory}

Agency theory originated from the work of Fama and Jensen, (1983); Ross, (1973); Jensen and Meckling, (1976). The theory mainly focuses on the relationship between a principal who delegates work and an agent who performs the duties as delegated. The theory was developed in the information economics to simulate the relationship between principals and agents in organization. The theory states that principals seek to influence agents in order to economize on these costs. The theory, building from assumptions that all actors are narrowly self-interested and agents are more risk averse than principals has earned a place of prominence (Eisenhardt, 1989). The volume of research showing that actors' self-interest is bounded by norms of fairness is gaining prominence in various fields as diverse as strategy (Ariño \& Ring, 2010; Fong \& Tosi, 2007; \& Conlon, Porter, \& Parks, 2004). Self-interested actors do seek to maximize their own self-interest, but only so long as perceived norms of fairness are not violated (Miller, 1999). When actors perceive fair treatment in competitive situations, they reward it through positively reciprocal behaviors; when they perceive unfair treatment, they punish it often at a cost to themselves through negatively reciprocal behaviors (Bosse, Phillips, \& Harrison, 2009; Uhl-Bien \& Maslyn, 2003) and thus principal-agent relations in an organization stand to influence its performance. This theory informs the constructs of corporate strategy and governance structure and eventually the organization performance.

\subsubsection{Institutional Theory}

Institutional theory postulates that organization corporate executives often make reference to norms and traditions applied in their industry to propose and formulate corporate policies to direct and control their entity (Meyer \& Rowan, 1977; Zucker 1987). The theory fronts the principles where systems are developed and adopted as guidelines to direct organizational behavior and norms. It explains how elements of organizational systems are created, adapted and eventually become obsolete. Donaldson and Preston (1995) argued that institutional theory emphasizes formal and legal aspects of governance structures. According to Scott (2005), institutional theory is a widely accepted theoretical framework that postulates rational myths and legitimacy.

The roots of institutional theory can be traced from the studies of economics, politics and sociology. Institutional theory focuses on the environmental factors experienced by an organization such as external or societal norms, rules, and requirements that organizations must conform to, in order to receive legitimacy and support. The theory depends heavily on the social constructs to help define the structure and processes of an organization. It postulates that society as a whole plays a vital role in determining the legitimacy of an organization and has much more power in the operations of an organization. It asserts that the institutional environment can strongly influence the development of formal structures in an organization, often more profoundly than market pressures.

Institutions are social structures that have attained a high degree of resilience. They are composed of cultural-cognitive, normative, and regulative elements that, together with associated activities and resources, provide stability and meaning to social life. According to the political and historical branches of institutional theory, institutions are emergent higher order factors above the individual level constraining or constituting the interests and political participation of actors. Thus institutions are formal or informal procedures, routines, norms and conventions in the organizational structure of the polity or the political economy. The sociological branch adds a cognitive script, moral templates and symbolic systems that may reside at suprastate or supraorganizational levels. Institutional theory underpins that for corporate strategy and governance structure to work and result in organizational performance, institutions must have proper systems, cultural settings and good governance structure.

\subsubsection{Upper Echelon Theory}

The theory was advanced by Hambrick and Mason (1984) and it postulates that organizational strategic choice, performance level and outcomes are partly determined by managers' characteristics and backgrounds. The theory was updated and the concept of managerial discretion was introduced (Hambrick \& Finkelstein, 1987). Hambrick 
and Fukutomi, 1991; Henderson, Miller, and Hambrick, 2006; Hambrick (2007) updated the theory to include more elements of top management attributes in an organization. The theory is applied in human capital management and helps in hiring new corporate managers. The theory has two interlocked assertions; executives act based on their personal interpretations of the strategic scenario they counter and these personal construals are attributes of the top managers' values, personalities and experiences. Equally, the theory is anchored on the foundation of bounded rationality (Cyert \& March, 1963; March \& Simon, 1958) emphasizing the fact that information complexity and uncertainty are not objectively 'knowable' but are simply interpretable. The theory postulates that for organizations to perform effectively, top management team must apply their values, personalities and experiences in order to influence their understanding of the situations they counter and in turn affects their strategic choice and other similar human factors. Thus corporate strategy and governance structure and eventually organization performance are impacted.

\subsubsection{Life Cycle Theory}

The theory was advanced by Franco Modigliani and his student Richard Brumberg in the early 1950s. The theory explains the stages that organizations go through during their life time. Burke, Lake and Paine, (2009) stated that management scholars have adopted the metaphor of organic growth as a heuristic device to explain development in an organization from its initial to its terminal state. They explain that external environmental situations and processes can affect how an entity represents itself and are always mediated by the imminent rules, logic or programs that govern the enterprise's development (Van de Ven \& Poole, 1995). Life-cycle model is a sequence that occurs cumulatively and conjunctively in an organization setup because the trajectory to the final results is predetermined and needs a unique historical sequence of activities where this event contributes to final outcome and must happen in a systematic order since each sets the stage for the next where each stage of development is seen as a necessary determinant of the succeeding stage. Therefore life-cycle theory in an organizational setup explains the development stage or phases that occur in an organization whose impact results in development of institutional programs or rules which need development activities to advance in a prefigured sequence or format. For example, Rogers fronted five stages of innovation which are need recognition, research on problem, development of ideas into useful form, commercialization and diffusion and adoption. The order among the stages is necessitated by logic and natural sequence.

The industry five forces and conditions of markets change over a period of time due to industry evolution and revolution resulting in formulation of strategy (Kamel, Frynas \& Finlay, 2005). Industry evolution and revolution may determine industry attractiveness thus influencing its investment opportunities and dictate organizations to adjust to remain relevant and serve their intended purpose. Industry evolution occurs when there are factors that affect the industry five forces and need strategic attention. Life-cycle model is important for understanding the course of industry evolution and this cycle is that every product advances through a cycle of four stages which are introduction, growth, maturity and decline which corresponds to the phases of industry stages. Product life cycle has major implications on the strategies an organization adopts since the industry forces will compel them to act in a particular way to remain relevant and competitive in their industry. This will explain the phases the company goes through thus affecting its performance.

\subsubsection{The Stakeholder Theory}

The theory defines the relationships and responsibility matrix that exists between the owners of an entity and the managers as well as the external partners. The proponent of the theory is Edward Freeman, who come up with the theory in 1988. The theory is the inner image of corporate social responsibility and it postulates that managers are to maximize shareholder interest and share values in accordance to permitted laws or social values. As much as an organization exists to increase shareholders' value, equally it has an obligation to its stakeholders and must fulfil their interest within the confines of legal and social justice (Parmar, Freeman, Harrison, Wicks, Purnell, \& De Colle, 2010).

The stakeholder theory is one of the various approaches that try to explain or rationalize strategy of organizations. It has its main underpinning on the emphasis placed on the role of stakeholders of a firm in the pursuit of its objectives. The stakeholders of a firm are viewed as being a critical factor to the survival of the organization. According to Friedman and Miles (2006), the concept is about how the organization should be and how it should be conceptualized. He states that the organization should be thought of as a grouping of stakeholders and its purpose should be to manage the interests, needs and viewpoints of the stakeholders. Managers must manage the organization for the benefit of the stakeholders, ensuring that their rights are taken care of and that they participate in decision making processes. The scholars argue that this is critical to the long term survival of the corporation. In a broader view, the concept of stakeholder view can be expressed in the sense that the role and purpose of the organization is 
not anymore guided by profit making and maximization of shareholders' wealth; but also to defend an image and values respecting the special relationships that arise and develop between it and all its stakeholders. The theory is much concerned with active management of the business environment, relationships and the promotion of shared interests in order to develop business strategies. The various proponents of the theory suggest differing ways of differentiating and categorizing stakeholders. Clarkson (1995) distinguishes stakeholders as primary and secondary, based on how vital the interdependence between the firm and the stakeholder is to the survival of the firm. Primary stakeholders are those without whose continuing participation the corporation cannot survive as a going concern. Secondary stakeholders are not as vital, but nevertheless have a role to play. Friedman and Miles (2006) list the main stakeholders of the organization as Customers, Employees, Local communities, shareholders, Suppliers and distributors.

\subsubsection{Balanced Scorecard Model}

The balanced scorecard model is a performance management tool which is supported by design methods and automation tools. It provides multidimensional performance evaluations and monitor strength and can help managers to keep track of the execution of activities by employees, measure both financial and non-financial outcomes resulting from their actions and take corrective measure where discrepancies arise. Kaplan and Norton (2001) suggested in their holistic tool of measuring firms performance-Balanced Score Card (BSC) that financial performance needs to be combined with other measures that will lead to future financial performance and which are non-financial metric which include satisfying stakeholders and customers, growth and survival of business and increased quality and efficiency. The study identifies the view held by the approach that will in measuring performance of the business it should be based on balanced score card which address both financial measure and nonfinancial measures (Kaplan \& Norton, 1996) than measure of only financial performance as suitable for adoption in relating strategies to performance.

\subsubsection{Theoretical Issues and Empirical Reviews}

The above review of theories relevant to this study reveals possibility of a relationship between the constructs of the study. First, Agency theory explains the relationship between the principals and agents in an organization and their role in the performance of an organization (Davis, Schoorman, \& Donaldson, 1997). It focuses on the people perspective in the organization. Secondly, the institutional theory focuses on the elements of norms, policies and programs that will enable the organization to operate in a relevant manner to the requirements of its context (Scott \& Davis, 2015). It further explains the effect of the governance structures on the performance of organization. Thirdly, Upper echelons theory explains the management attributes of the organization. Fourthly, lifecycle theory explains the phases the organization has to go through and strategic alertness it requires to go through each phase and finally the stakeholder theory defines the relationships and responsibility matrix that exists between the owners of an entity and the managers as well as the external partners. Balanced scorecard addresses performance management of the organization and how it should target to achieve its strategic objectives while taking into consideration both financial and non-financial perspectives of organization performance.

A review of the empirical literature shows evidence on how previous researches have integrated postulates of the theories in empirical work. Okiro, Aduda and Omoro (2015) investigated the effect of corporate governance and capital structure on performance of firms listed at the East African community securities exchange and anchored it on Agency theory; Marashdeh (2014) studied the effect of corporate governance on Firm Performance in Jordan and supported the study with the agency theory; Heenetigala (2011) examined corporate governance practices and firm performance of listed companies in Sri Lanka and anchored the study on the agency theory.

From the empirical literature reviewed so far, it is however noted that there are limited theories applied to support the linkage and the relationship between the constructs of the study. Anwar, Shah and Hasnu (2016) studied business strategy and organizational performance and applied the Miles and Snow typology or model of management; Oyedijo and Akewusola (2012) studied organizational strategy and firm performance anchoring the study on the Miles and Snow's model; Aftab, Ehsan, Naseer and Awan (2012) investigated the effect of corporate strategy and capital structure on performance of banking sector of Pakistan and anchored the study on contingency theory; Kalkana, Erdilb and Çetinkayac (2011) researched on the relationships between firm size, prospector strategy, architecture of information technology and firm performance in Isparta, in Turkey, Miles and Snow's model being the underpinning management model; Ray (2004) examined Environment-Strategy-Performance Linkages and applied contingency theory.

Based on these observations, there is need to propose a multidisciplinary theoretical model anchored on the above discussed theories and management models to investigate the relationships to advance knowledge on the constructs and in general strategic management field. 


\section{The Call for a Theoretical Model}

The literature so far reviewed has raised a number of issues that present a call for a new theoretical framework to model the phenomenon involving corporate strategy, governance structure and performance in a strategic management context. First, the theoretical review has pointed at the complimentarity that exists among the diverse theories that underpin the phenomenon and the need to capture emerging benefits of this complimentarity in informing scholarship in strategic management. Secondly, emerging from this complimentarity is the aspect of the broadened perspective to the construct of performance using the stakeholder lens so as to link corporate strategies with the broader meaning of the construct and its operational indicators. Alongside this consideration is the identified comprehensive set of indicators of the constructs using the diverse views of the constructs borrowed from both conceptual and empirical literatures. Lastly the emerging phenomenon needs to designate the possible roles at the abstraction level such that scholarly efforts can further test the roles at an empirical level. Doing so would ensure that the scientific methodological expectations to the advancement of knowledge is satisfied based on both ontological and epistemological considerations which support the view that advancement of new knowledge calls for theoretical models (theories) that affirm empirical work. Nachmias and Nachmias (2004) pesent two strategies to the place of theory in advancing scientific knowledge. The strategy advocating theory before research bases its arguments on the fact that a theoretical framework supports a research study theory by constructing an explicit theory or model, selecting a proposition derived from the theory and modelling for empirical investigation and designing a research project to test propositions. The authors rely on previous attempts for advancement of knowledge in strategic management (Wandiga, Kilika, \& James, 2017 ; Nachmias \& Nachmias, 2004; Oduour \& Kilika, 2018; Kimiti \& Kilika 2018) to justify a case for proposing a new theoretical model. In view of these considerations, the authors propose the model linking corporate strategy, competitive position and organizational performance in the context of gorvenance structure and industry lifecycle stage.

\subsection{The Proposed Theoretical Model}

The proposed model provides three levels of consideration of constructs in the phenomenon. The antecedent factor is corporate strategy which has been operationalized using the indicators of growth strategy, stability strategy and retrenchment strategy. The ultimate condition of the proposed phenomenon is that of performance which has been operationalized using two perspectives namely financial and non financial perspectives. The intermediate condition is represented by the firm competitive position which has been operationalized through three indicators of quality, service and cost leadership. The contingent factors included are governance structure and industry lifecycle stage. The phenomenon emerging from the discussions and the proposed theoretical framework is summarised in figure 1. 


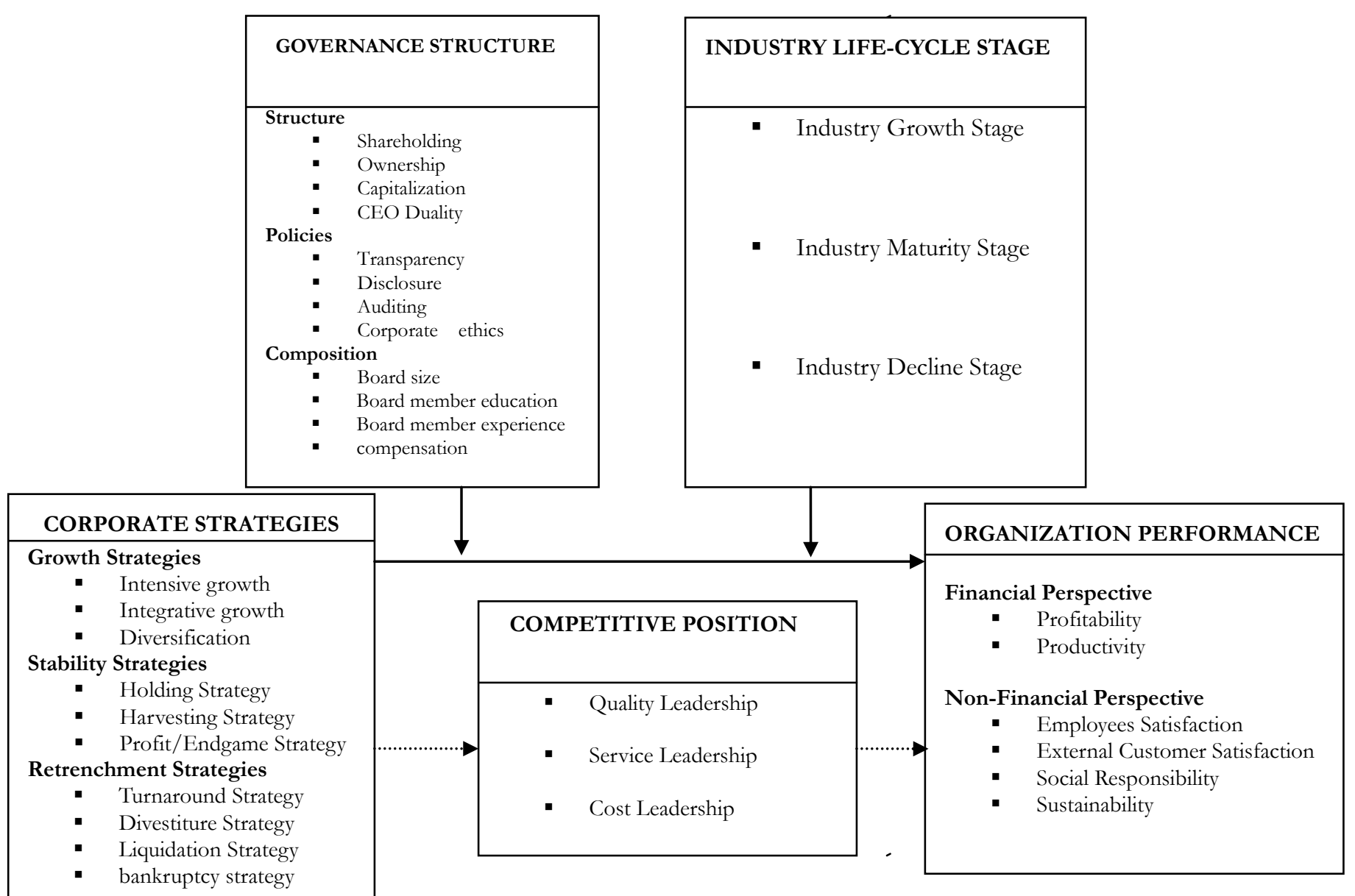

Figure 1. Theoretical Model linking Corporate Strategy, Governance Structure and Organization Performance

\subsection{Propositions}

\subsubsection{Corporate Strategy and Organization Performance}

The proposed model has the construct of corporate strategy as the antecedent factor in the strategic management phenomenon linking corporate strategy and organizational performance. In most cases, the typical strategic management process has as its main focus the choice of a relevant strategy so as to achieve organizational performance. The strategic management process that recognizes three levels of strategy emphasizes the role of the corporate level in setting the long term direction for an organization. This sense of direction is set through an articulated mission, objectives and a corresponding corporate strategy that will achieve the expectations of the mission and objectives. Organizations ensure that the chosen strategy reflects a careful analysis of the external context of the firm so that each strategy is considered relevant and appropriately fits the firm in its changing context. Consistent with the work of Pearce and Robinson, (2011) three types of strategies that are at the heart of corporate strategy are proposed to be critical to establishing a path that will result in the desired performance of organizations. The nature of these strategies is such that they respond to the situations faced by the organization and generate actions that will lead to the desired performance of the firms (Wandiga, Kilika \& James, 2017). Thus proposition one is stated;

Proposition One: Relevant Corporate strategies adopted by organizations in response to the phase of industry life cycle of the company will influence performance of the organization.

\subsubsection{The Role of Firm Competitive position}

The strategies applied by a firm are aimed at providing needed capabilities for sustaining performance. In the context of a competitive environment, one of the required forms of capability is that of attaining a competitive position in the industry or market. Competitive positioning is a deliberate strategic choice organizations make where they opt to be within the industry either as a service, quality or cost leader. It is a powerful tool that allows a firm to create an image (Munyoki, 2015). It enables an organization identify itself to its targeted market niche and easily attract 
them. Kotler and Keller (2013) argued that in the maturity arena there are three types of organization which are quality leaders, service leaders and cost leaders. Surrounding them are market nichers (market specialists, product specialist and customizers). The questions to corporate strategists are whether to struggle to become one of the big three and achieve profits through high volumes and low cost or pursue a niching strategy and profit by low volumes and high margins. It is the view of the authors that strategically conscious firms will seek to implement their chosen corporate strategies with the aim of creating this intermediate condition as their base for sustaining their desired level of performance. Thus we propose:

Proposition Two: Well developed corporate strategy will lead to the attainment of a desired competitive position by a firm as a necessary condition for sustaining the desired firm performance

Proposition Three: The strength of the relationship between the corporate strategies adopted and desired performance level will be determined by the firm competitive position generated from the corporate strategies.

\subsubsection{The Role of Governance Structure}

Every organization sets up shop to achieve a long term objective as stated in its mission and vision, but to realize this dream corporate entities must have in place excellent corporate strategies and suitable governance structure. Corporate managers are not only mandated to develop corporate strategies in line with organization mission and vision but must also think about the systems, policies, procedures, rules, plans and programs to implement and control the same corporate strategies in order to achieve the desired organizational performance. Governance structure provides direction on how the organization should operate so as to achieve organization performance. Therefore the state and ability of governance structure adopted by an organization determines the types of corporate strategies that the organization develops and implements thus eventually affecting the performance of the organization. The superior the governance structure the better the corporate strategies adopted resulting in excellent performance of an organization.

Proposition Four: Although corporate strategy has potential to influence the firm performance level, the level of influence is contingent upon the governance structure the firm has put into place.

\subsubsection{The Role of Industry Life-Cycle}

Organizations do not operate in a vacuum but in an environment with a host of factors that influence organization's choice of direction and action and ultimately its organization structure, internal processes and eventually its performance (Pearce \& Robinson, 2011). These environmental factors which constitute the external environment can be divided into remote, industry and operating environment. The industry within where an organization operates has to be taken into consideration to make decisions that enable the firm to appropriately fit in its context. These factors are characterised by dynamism and turbulence, and influence the performance of an organisation. However, Galbreath and Galvin, (2008) cited that in today's business environment, structural characteristics of industries are viewed as less important predictors of organizational performance while organizational resources are seen as the pillar upon which firms compete. The industry factors include and among others government regulation, political, social, economic, competitors, suppliers, customers, labour and technological changes which cannot be controlled by an organization and constrain the organization's ability to attaining its desired performance. Different organizations address these factors depending on their industry life-cycle stage. Industry life-cycle can be classified into growth, maturity and decline stage. Therefore it is inevitable to link the adopted corporate strategies and industry stage to achieve the desired organizational performance as depicted in the mission and vision governing the organization. Thus proposition five is stated as;

Proposition Five: Although corporate strategy has potential to influence firm performance, the level of influence will be contingent upon the degree to which the firm's strategies have integrated the demands of the life cycle stage the industry is in.

\section{Conclusion and Direction for Further Research}

The purpose of this paper was to review the extant conceptual, theoretical and empirical literatures on the constructs of corporate strategy, governance structure and performance inorder to identify emergent gaps and propose a theoretical model for guiding future research. The authors attempted to trace the nature and characteristics of the various constructs from the works of diverse scholars as well as their operational indicators. The study adopted a broad range of scholarship drawn not only from strategic managment but also from organization theory, marketing and orgnizational development and change managment to conceptualize the constructs of the study and provided conceptul understanding, operational indicators and linkages among the constructs.. 
The discussions in the paper endeavoured to trace the anchorage of the constructs to the relevant theories using a multidisciplinary perspective. The paper anchored the constructs on the postulates of Agency Theory, Institution theory, Upper Echelon theory, Lifecycle Theory, Stakeholder Theory and Balanced Score Card approach. The arguments drawn from these theories were used first, to identify complimentarities among the theories in away that enables scholarship to clearly understand the nature of the emerging issues and, secondly for identifyng empirical studies in which researchers have attempted to apply the theories in previous empirical work that have studied the constructs. Even though the literature indicated that the theories have been applied in some researches, a great deal of the researches have not applied the theories to investigate the constructs used to propose a new theoretical model in this study.

The study identified relevant calls that justify the case for proposing a new theoretical model and linked this call to the expectations of the scientific methodology. Toward this, the study proposed a theoretical model based on the emerging phenomenon that links the constructs. In the framework constructs were designated relevant roles and the nature of the linkages among the constructs expressed as appropriate propositions.Thus through the proposed theoretical framework, the study not only provides a new theory lining corporate strategy and performance in the context of gorvenance sructure and competitive position but also points at the direction for future research on these constructs that build the theoretical model. While the study makes this attempt, the authors however are aware of the limitations of the propositions in that the conclusions pointed at may only hold to the extent of justification supported by the theoretical literature and thus there is need for empirical attempts to verify the claims made in this paper. The authors therefore call upon future research to undertake empirical work with a view to developing data collection instruments using the indicators of the constructs, obtain primary data and empirically test the emergent propositions using appropriate stastical techniques.

\section{References}

Aftab, M., Ehsan, R., Naseer, S., \& Awan, T. (2012). The Effect of Corporate Strategy and Capital Structure on Performance of Banking Sector of Pakistan. Global Journal of Management And Business Research, 12(17).

Anwar, J., Shah, S., \& Hasnu, S. (2016). Business strategy and organizational performance: measures and relationships. Pakistan Economic and Social Review, 54(1), 97.

Ansoff, H. I. (1980). Strategic issue management. Strategic management journal, 1(2), 131-148. https://doi.org/10.1002/smj.4250010204

Ariño, A., \& Ring, P. S. (2010). The role of fairness in alliance formation. Strategic Management Journal, 31(10), 1054-1087. https://doi.org/10.1002/smj.846

Awaluddin, M. (2014). The Effect Of Corporate Strategy To Company Performance (A survey In businesses unit of Pt. Telekomunikasi Indonesia, Tbk). https://doi.org/10.15242/ICEHM.ED1214156

Bosse, D. A., Phillips, R. A., \& Harrison, J. S. (2009). Stakeholders, reciprocity, and firm performance. Strategic Management Journal, 30(4), 447-456. https://doi.org/10.1002/smj.743

Burke, W. W., Lake, D. G., \& Paine, J. W. (2009). Some conclusions and future needs-Editors interlude. Article in Book Organisation change: A comprehensive reader. Jossey Bass, San Francisco, CA

Child, J. (1972). Organizational structure, environment and performance: The role of strategic choice. sociology, 6(1), 1-22. https://doi.org/10.1177/003803857200600101

Christensen, R. (2006) Roadmap to strategic HR: Turning a great idea into a business reality. AMACOM Div American Mgmt Assn.

Clarkson, M. E. (1995). A stakeholder framework for analyzing and evaluating corporate social performance. Academy of management review, 20(1), 92-117. https://doi.org/10.2307/258888

Conlon, D. E., Porter, C. O., \& Parks, J. M. (2004). The fairness of decision rules. Journal of Management, 30(3), 329-349. https://doi.org/10.1016/j.jm.2003.04.001

Cyert, R. M., \& March, J. G. (1963). A behavioral theory of the firm. Englewood Cliffs, NJ, 2, 169-187.

Davis, J. H., Schoorman, F. D., \& Donaldson, L. (1997). Toward a stewardship theory of management. Academy of Management review, 22(1), 20-47. https://doi.org/10.2307/259223

Donaldson, T., \& Preston, L. E. (1995). The stakeholder theory of the corporation: Concepts, evidence, and implications. Academy of management Review, 20(1), 65-91. https://doi.org/10.2307/258887 
Duc, V. H., \& Thuy, P. B. G. (2013). Corporate governance and firm's performance: empirical evidence from Vietnam. Journal of Economic Development, (JED, No. 218), 62-77. https://doi.org/10.24311/jed/2013.218.08

Eisenhardt, K. M. (1989). Agency theory: An assessment and review. Academy of management review, 14(1), 57-74. https://doi.org/10.5465/amr.1989.4279003

Fama, E. F., \& Jensen, M. C. (1983). Agency problems and residual claims. The Journal of Law and Economics, 26(2), 327-349. https://doi.org/10.1086/467038

Fratini, F., \& Tettamanzi, P. (2015). Corporate governance and performance: Evidence from Italian companies. Open Journal of Business and Management, 3(02), 199. https://doi.org/10.4236/ojbm.2015.32020

Freeman, R. E. (2010). Strategic management: A stakeholder approach. Cambridge university press. https://doi.org/10.1017/cbo9781139192675.007

Filatotchev, I., \& Wright, M. (2011). Agency perspectives on corporate governance of multinational enterprises. Journal of Management Studies, 48(2), 471-486. https://doi.org/10.1111/j.1467-6486.2010.00921.x

Friedman, A.L.\&Miles,S.(2006). Stakeholders:Theory and Practice. Oxford University Press.

Galbraith, C., \& Schendel, D. (1983). An empirical analysis of strategy types. Strategic Management Journal, 4(2), 153-173. https://doi.org/10.1002/smj.4250040206

Galbreath, J., \& Galvin, P. (2008). Firm factors, industry structure and performance variation: New empirical evidence to a classic debate. Journal of business research, 61(2), 109-117. https://doi.org/10.1016/j.jbusres.2007.06.009

Govindarajan, V., \& Fisher, J. (1990). Strategy, control systems, and resource sharing: Effects on business-unit performance. Academy of Management journal, 33(2), 259-285. https://doi.org/10.2307/256325

Greiner, L. E. (1989). Evolution and revolution as organizations grow. In Readings in strategic management (pp. 373-387). Palgrave, London. https://doi.org/10.1007/978-1-349-20317-8_25

Hambrick, D. C. (2007). Upper echelons theory: An update. Academy of management review, 32(2), 334-343. https://doi.org/10.5465/amr.2007.24345254

Hambrick, D. C., \& Fukutomi, G. D. (1991). The seasons of a CEO's tenure. Academy of management review, 16(4), 719-742. https://doi.org/10.2307/258978

Hambrick, D. C., \& Finkelstein, S. (1987). Managerial discretion: A bridge between polar views of organizational outcomes. Research in organizational behavior. psycnet.apa.org

Hambrick, D. C., \& Mason, P. A. (1984). Upper echelons: The organization as a reflection of its top managers. Academy of management review, 9(2), 193-206. https://doi.org/10.5465/amr.1984.4277628

Heenetigala, K. (2011). Corporate governance practices and firm performance of listed companies in Sri Lanka (Doctoral dissertation, Victoria University).

Henderson, A. D., Miller, D., \& Hambrick, D. C. (2006). How quickly do CEOs become obsolete? Industry dynamism, CEO tenure, and company performance. Strategic Management Journal, 27(5), 447-460. https://doi.org/10.1002/smj.524

Johnson, G., Scholes, K., \& Whittington, R. (2008). Exploring corporate strategy: text \& cases. Pearson Education.

Johnson, G., Whittington, R., \& Scholes, K. (2010). Exploring strategy. 9. Aufl. Harlow: Pearson. Google Scholar. https://doi.org/10.4135/9781473915244.n8

Kalkan, A., Erdil, O., \& Çetinkaya, Ö. (2011). The relationships between firm size, prospector strategy, architecture of information technology and firm performance. Procedia-Social and Behavioral Sciences, 24, 854-869. https://doi.org/10.1016/j.sbspro.2011.09.114

Kamel, M., Frynas, J. G., \& Finlay, P. N. (2005). Global strategic management, New Jersey: Oxford University Press

Kaplan, R. S., \& Norton, D. P. (2001). The strategy-focused organization. Strategy and Leadership, 29(3), 41-42. https://doi.org/10.1108/s1.2001.26129cab.002

Kaplan, R.S. \& Norton, P. (1996). The Balance Score Card: Translating Strategy into Action. Boston MA. Harvard Business School Press. https://doi.org/10.1016/S0024-6301(97)80925-9

Kimiti,P.G. \& Kilika,J.M. (2018). Organization resources, industry velocity, attention focus and firm's performance; 
A review of literature. https://doi.org/10.5539/ijbm.v13n5p185.

Kotler, P., \& Keller, K. L. (2013). Marketing management. 14. vyd. Praha: Grada, 2013. 816 s. ISBN 978-80-247-4150-5.

Kuratko, D. F., Covin, J. G., \& Garrett, R. P. (2009). Corporate venturing: Insights from actual performance. Business Horizons, 52(5), 459-467. https://doi.org/10.1016/j.bushor.2009.05.001

Malmi, T., \& Brown, D. A. (2008). Management control systems as a package Opportunities, challenges and research directions. Management accounting research, 19(4), 287-300. https://doi.org/10.1016/j.mar.2008.09.003

Marashdeh, Z. M. S. (2014). The effect of corporate governance on firm performance in Jordan (Doctoral dissertation, University of Central Lancashire).

March, J. G., \& Simon, H. A. (1958). Organizations. psycnet.apa.org

Marshall, C., \& Rossman, G. B. (2014). Designing qualitative research. Sage publications.

Michel, J. G., \& Hambrick, D. C. (1992). Diversification posture and top management team characteristics. Academy of Management journal, 35(1), 9-37. https://doi.org/10.5465/256471

Miller, D. T. (1999). The norm of self-interest. American Psychologist, 54(12), 1053. https://doi.org/10.1037//0003-066x.54.12.1053

Mintzberg, H. (1987). Crafting strategy (pp. 66-75). Boston: Harvard Business Review.

Muchemi, A. W. (2013). Top management team diversity and performance of commercial banks in Kenya. Unpublished PhD Thesis, University of Nairobi.

Munyoki, C. (2015). Competitive strategies, organizational autonomy, positioning and performance of Kenyan state corporations. Unpublished PhD thesis), University of Nairobi.

Nachmias, C.F. \& Nachmias, D. (2004). Research Methods in the Social Sciences, 5th Ed. London: Arnold. Administrative Science Quarterly, 20, 546-558. https://doi.org/10.1037/e540052004-001

Oduor,B.A. \& Kilika,J.M. (2018). TMT Diversity, decision quality and service $\quad$ sector $\quad$ firm performance https://doi.org/10.5430/jms.v9n2p34.

Okiro, K., Aduda, J., \& Omoro, N. (2015). The effect of corporate governance and capital structure on performance of firms listed at the East African community securities exchange. European Scientific Journal, ESJ, 11(7).

Oyedijo, A., \& Akewusola, R. O. (2012). Organizational Strategy and Firm Performance: A Test of Miles and Snow s Model Using 34 Paint Manufacturing SMEs in Southwestern Nigeria. Journal of Research in International Business and Management, 2(6), 170-178.

Parmar, B. L., Freeman, R. E., Harrison, J. S., Wicks, A. C., Purnell, L., \& De Colle, S. (2010). Stakeholder theory: The state of the art. Academy of Management Annals, 4(1), 403-445. https://doi.org/10.5465/19416520.2010.495581

Pearce, J. A., \& Robinson, R. B.. (2011). Strategic management: Formulation, implementation, and control. Columbus, OH: Irwin/McGraw-Hill.

Pfeffer, J. (1972). Size and composition of corporate boards of directors: The organization and its environment. Administrative science quarterly, 218-228. https://doi.org/10.2307/2393956

Porter, M. E. (2008). Competitive strategy: Techniques for analyzing industries and competitors. Simon and Schuster. https://doi.org/10.1016/0019-8501(82)90025-6

Porter, M. E. (1980). Industry structure and competitive strategy: Keys to profitability. Financial Analysts Journal, 36(4), 30-41. https://doi.org/10.2469/faj.v36.n4.30

Ray, S. (2004). Environment-strategy-performance linkages: A study of Indian firms during economic liberalization. Vikalpa, 29(2), 9-24. https://doi.org/10.1177/0256090920040202

Reeves, M., Love, C., \& Tillmanns, P. (2012). Your strategy needs a strategy. Harvard Business Review, 90(9), 76-83.

Rezaee, Z. (2009). Corporate governance and ethics. John Wiley \& Sons.

Richard, P.J., Devinney, T.M., Yip, G.S. \& Johnson, G. (2009). Measuring organizational

performance: Towards methodological best practice. Journal of Management, (35)3,718-804. https://doi.org/10.1177/0149206308330560 
Risse, T. (2004). Global governance and communicative action. Government and opposition, 39(2), 288-313. https://doi.org/10.1111/j.1477-7053.2004.00124.x

Santos, J. B., \& Brito, L. A. L. (2012). Toward a subjective measurement model for firm performance. BAR-Brazilian Administration Review, 9(SPE), 95-117. https://doi.org/10.1590/s1807-76922012000500007

Schendel, D., \& Hofer, C. W. (Eds.). (1979). Strategic management: A new view of business policy and planning. Little, Brown.

Scott, W. R. (2005). Institutional theory: Contributing to a theoretical research program. Great minds in management: The process of theory development, 37, 460-484.

Scott, W. R., \& Davis, G. F. (2015). Organizations and organizing: Rational, natural and open systems perspectives. Routledge.

Sekhar, G. S. (2009). Business policy and strategic management. IK International Pvt Ltd.

Thompson, A. A., \& Strickleand, A. J. (1996). Strategic management: Concepts and cases. Long Range Planning, 6(29), 907-908. infona.pl

Tashakkori, A., \& Teddlie, C. (Eds.). (2010). Sage handbook of mixed methods in social \& behavioral research. Sage.

Uhl-Bien, M., \& Maslyn, J. M. (2003). Reciprocity in manager-subordinate relationships: Components, configurations, and outcomes. Journal of Management, 29(4), 511-532. https://doi.org/10.1016/s0149-2063_03_00023-0

Wandiga, E. N., Kilika, J. M., \& James, R. (2017). Firm Performance in the Context of Knowledge Based Intensive Sector: A Theoretical Review. International Journal of Business and Management, 12(8), 234. https://doi.org/10.5539/ijbm.v12n8p234

Wildavsky, A. (1973). If planning is everything, maybe it's nothing. Policy sciences, 4(2), 127-153. https://doi.org/10.1007/bf01405729

Van de Ven, A. H., \& Poole, M. S. (1995). Explaining development and change in organizations. Academy of management review, 20(3), 510-540. https://doi.org/10.2307/258786 